\title{
Hasil Studi Pola Kebakaran Lahan Gambut melalui Citra Satelit Sentinel-2 dengan Pengimplementasian Machine Learning Metode Random Forest: Kajian Literatur
}

\section{(Outcome Study of Fire Patterns on Peatland Using Sentinel-2 Satellite's image by Using Machine Learning's Implementation Random Forest Method: Literature Review)}

\author{
Annisa Rizky Kusuma1, Fauzan Maulana Shodiq1, M. Faris Hazim¹ Dany Puguh Laksono \\ ${ }^{1}$ Mahasiswa Departemen Teknik Geodesi ,Universitas Gadjah Mada, Indonesia \\ 2 Departemen Teknik Geodesi, Universitas Gadjah Mada, Indonesia
}

Penulis Korespondensi: Dany Puguh Laksono | Email: danylaksono@ugm.ac.id

Diterima (Received): 25/10/202 Direvisi (Revised): 12/11/2021 Diterima untuk Publikasi (Accepted): 08/12/2021

\begin{abstract}
ABSTRAK
Kebakaran lahan gambut merupakan peristiwa yang sulit diprediksi perilakunya. Karakteristik tanah gambut yang kompleks dan faktor-faktor alam lain seperti arah angin, status vegetasi, dan kandungan air membuat kasus ini menjadi salah satu kasus menarik yang masih menjadi objek penelitian yang belum tuntas hingga saat ini. Ketika memasuki musim kemarau kondisi kadar air di dalam tanah gambut akan semakin berkurang, maka potensi terjadinya kebakaran akan semakin tinggi. Pada studi ini dilakukan analisis faktor penyebab kebakaran dengan area cakupan yang luas melalui satelit Sentinel-2. Citra satelit yang diperoleh nantinya akan diolah oleh machine learning untuk memprediksi penyebaran api. Hasil literatur yang telah dilakukan diperoleh bahwa Ground Water Level (GWL), kematangan gambut, suhu, curah hujan dan kelembaban, serta kerapatan vegetasi dapat diidentifikasi melalui perhitungan indeks. Indeks yang digunakan diantaranya indeks Differenced Normalized Difference Vegetation Index (dNDVI) dan Normalized Difference Water Index (NDWI) yang diolah dengan algoritma machine learning metode Random Forest memiliki akurasi mencapai $96 \%$.
\end{abstract}

Kata Kunci: gambut, kebakaran, citra satelit, machine learning

\section{ABSTRACT}

Peatland fire is an event with unpredicted behavior. The complexity of peatland's characters and other natural factors such as winds direction, vegetations status, and contents of water made this one of unique cases that still remain unfinished research's object till today. The lower contents of water in peatland accompanied with dry season, the higher of the risk of fire. In this study, an analysis of the causes of fires was carried out with a wide coverage area via the Sentinel-2 satellite. The satellite images obtained will be processed by machine learning to predict the spread of fire. The results of the literature that have been carried out show that Ground Water Level (GWL), peat maturity, temperature, rainfall and humidity, and vegetation density can be identified through index calculations. The indexes used include the Differenced Normalized Difference Vegetation (dNDVI) and the Normalized Difference Water (NDWI) which were processed using a machine learning algorithm using the Random Forest method, with an accuracy of $96 \%$.

Keywords: peat, fire, satellite's image, machine learning

(C) Author(s) 2021. This is an open access article under the Creative Commons Attribution-ShareAlike 4.0 International License (CC BY-SA 4.0)

\section{Pendahuluan}

Kebakaran hutan dan lahan merupakan suatu peristiwa yang dapat terjadi secara alami maupun oleh perbuatan manusia, yang ditandai dengan penjalaran api dengan bebas serta mengkonsumsi bahan bakar hutan dan lahan yang dilaluinya (Adinugroho, 2004). Peristiwa kebakaran hutan di Indonesia selalu terjadi pada periode waktu dan wilayah yang relatif sama. Berdasarkan data Sipongi Kebakaran Hutan dan Lahan (2019), sepanjang bulan Januari sampai September 2019 telah terjadi kebakaran hutan dan lahan seluas 857.756 hektar di seluruh 
Indonesia. Kebakaran memakan 630.451 hektar lahan mineral dan 227.304 hektar di lahan gambut. Angka ini meningkat $160 \%$ jika dibandingkan luasan Agustus lalu, sekitar 328.724 hektar. Hutan dan lahan yang paling banyak terbakar berada di Kalimantan Tengah, mencapai 134.227 hektar, kemudian diikuti oleh Kalimantan Barat seluas 127.462 hektar, dan Nusa Tenggara Timur 119.459 hektar (Direktorat Pengendalian Kebakaran Hutan dan Lahan, Kementerian Lingkungan Hidup dan Kehutanan RI, 2019). Berdasarkan data tersebut menunjukkan bahwa lahan yang kerap terbakar di Indonesia setiap tahunnya ialah lahan mineral dan lahan gambut (Media Indonesia, 2019).

Perbedaan dari karakteristik kedua tanah adalah tanah mineral memiliki kandungan bahan organik yang rendah sedangkan tanah gambut memiliki kandungan bahan organik yang tinggi. Pada kondisi gambut terdegradasi akibat pembukaan lahan dan pembuatan drainase, air gambut akan mudah mengalir ke luar sehingga gambut menjadi kering. Keringnya gambut membuat gambut menjadi bahan bakar potensial yang sangat mudah terbakar (Laboratorium Kebakaran Hutan dan Lahan IPB, 2018). Dalam perkembanganya, api menjalar secara vertikal dan horizontal berbentuk seperti kantong asap dengan pembakaran yang tidak menyala (smoldering) sehingga hanya asap yang berwarna putih saja yang tampak di atas permukaan (Adinugroho, 2004).

Dengan memanfaatkan bantuan teknologi modern seperti machine learning, fenomena pola kebakaran hutan di lahan gambut ini dapat diinvestigasi dan dibuatkan pemodelan dengan metode random forest. Metode lain yang telah dilakukan untuk memprediksi titik kebakaran dengan metode Fuzzy Analytic Hierarchy Process (FAHP). Namun, metode ini kurang efektif jika dibandingkan dengan metode random forest sebab hasil model bergantung pada pemberian skor. Sedangkan, metode random forest dapat mempelajari sampel data yang tidak saling berkorelasi. Hasil dari metode ini pun memiliki tingkat kesalahan yang rendah (Yiu, 2019). Oleh karena itu, studi ini dilakukan untuk menganalisis potensi pola kebakaran dengan metode random forest pada Citra Satelit Sentinel-2. Hasil studi pola kebakaran ini sangat bermanfaat untuk mengedukasi parameter terjadinya kebakaran lahan gambut kepada masyarakat sehingga dapat melakukan mitigasi bencana lebih dini dan mengurangi kerugian lingkungan yang ditimbulkan.

\section{Data dan Metodologi}

Metode yang digunakan dalam penyusunan penulisan merupakan hasil kajian literatur pada tinjauan pustaka yang didapatkan korelasi antara faktor-faktor pembentukan kebakaran hutan di lahan gambut dan prediksi kebakaran lahan gambut menggunakan implementasi dari machine learning. Hasil kajian literatur ini berisi tentang berbagai hasil penelitian terkait faktorfaktor kebakaran lahan gambut dan machine learning.
Dalam prosesnya, kajian literatur ini membantu membuat sebuah alur proses dari awal sampai akhir yang bersumber dari mengumpulkan banyak studi dan literatur terkait judul penelitian, yang kemudian diambil intisarinya dan dianalisis korelasi antar literatur tersebut. Total referensi yang digunakan sejumlah 24 dengan rincian 2 textbook, 3 jurnal konferensi, 6 jurnal nasional. dan 13 jurnal internasional.

\section{Hasil dan Pembahasan}

Beberapa penelitian yang dijadikan bahan studi ini dapat dituliskan sebagai berikut:

\subsection{Kebakaran Hutan dan Lahan Gambut}

Hingga tahun 2018, fenomena El Niño-Southern Oscillation (ENSO) digunakan sebagai alasan untuk menjelaskan kebakaran lahan gambut di Indonesia (Kasihairani, et al., 2014). Namun sewaktu tahun 2019 timbul kebakaran yang independen terhadap El Niño, dibutuhkan indikator dan metode yang lebih mumpuni untuk (a) menganalisis, (b) mengevaluasi dan (c) memprediksi kebakaran lahan gambut. Hayasaka, et al., (2020) menganalisis kebakaran lahan gambut terbesar dalam rentang waktu 6 tahun dari 2002 hingga 2018 dan menemukan bahwa kebakaran lahan gambut terjadi dalam tiga tahapan-kebakaran permukaan, kebakaran gambut dangkal, dan kebakaran gambut dalam. Untuk menjelaskan setiap tahapan, diusulkan model prediksi Ground Water Level (GWL) satu-dimensi dengan nama MODEL-0. MODEL-0 memprediksi GWL dari curah hujan harian. Adapun pentingnya GWL dalam studi tersebut ialah dikarenakan adanya korelasi antara GWL terhadap timbulnya kebakaran hutan oleh hasil studi dari Ishii, et al. (2016) yang menemukan bahwa pada gambut yang mengalami penurunan GWL lebih dari $2 \mathrm{~m}$ di bawah tanah timbul kebakaran hutan pada tahun 2009. Model-0 dapat dilihat di Gambar 1.

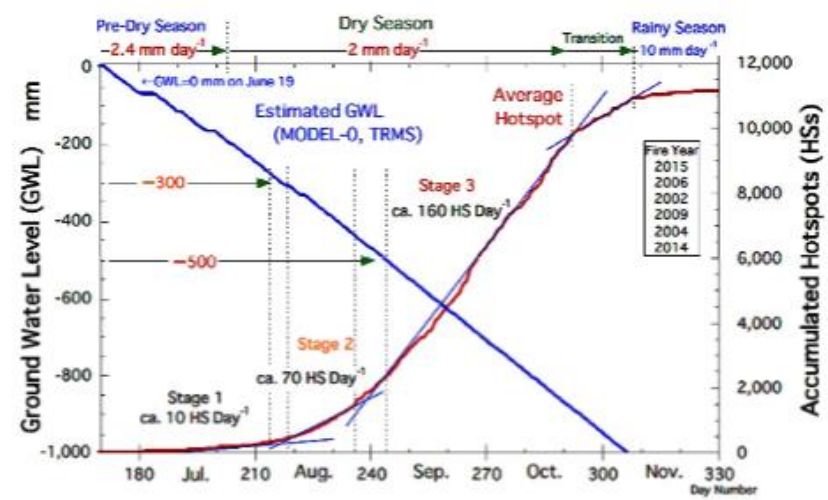

Gambar 1 Aktivitas rata-rata kebakaran pada musim kebakaran El Nino dan GWL terestimasi menggunakan Model-0 (Hayasaka, et.al., 2010)

Penelitian yang dilakukan oleh Ratnaningsih dan Prasytaningsih (2017) di lokasi penelitian yang memiliki 
kedalaman gambut sebesar 600-800 cm mengkaji bagaimana pengaruh karakteristik gambut terhadap kebakaran yang terjadi. Konten serat gambut pada lapangan berkisar antara 38 hingga 75, diklasifikasikan sebagai gambut hemik. Kepadatan curah rata-ratanya ialah 0.253 gram cm-3 (0.087-0,896 gram cm-3). Konten abu tanah sebanyak 2,24\% dan stok karbon gambut yang disimpan dengan ketebalan 8 meter adalah 10723,69 ton ha-1. Kebakaran hutan diprediksi telah membakar gambut hingga kedalaman $100 \mathrm{~cm}$ dan melepaskan emisi CO2 sebanyak 6,355,809 tons ha-1. Karakteristik kedalaman gambut adalah faktor utama dalam memperkirakan stok karbon pada lahan gambut.

Kedalaman tanah gambut yang diteliti adalah lebih dari 10 meter dengan karakteristik memiliki selulosa bebas dengan kelembaban normal berkisar antara 60-70\% dan kandungan karbon mencapai $60 \%$. Tanah gambut ini mempunyai kemampuan menyerap air yang berkaitan dengan ketersediaan gugus karboksilat dan $\mathrm{OH}$-fenolat dalam bahan gambut (Masganti, 2014)

Penetrasi suhu tinggi dari kebakaran permukaan hingga ke lapisan gambut yang lebih dalam ditentukan oleh banyak faktor seperti level suhu, durasi kebakaran, kandungan air pada gambut, dan kualitas gambut. Berdasarkan penelitian Babrauskas (2003), jika lapisan gambut dipanaskan lebih lama dari 2 jam, suhu ignisi akan turun sebesar $150-160^{\circ} \mathrm{C}$.

Tabel 1 Karakteristik pembakaran gambut. (Usup, et.al., 2004)

\begin{tabular}{cccccc}
\hline $\begin{array}{l}\text { Kedalaman } \\
\text { Gambut (cm) }\end{array}$ & $\begin{array}{c}\text { Tv } \\
\text { (C) }\end{array}$ & Tc (C) & $\begin{array}{c}\Delta \mathbf{W d} \\
\mathbf{( \% )}\end{array}$ & $\begin{array}{c}\Delta \mathbf{W v} \\
(\mathbf{\%})\end{array}$ & $\begin{array}{c}\text { Cc } \\
(\%)\end{array}$ \\
\hline \multicolumn{7}{c}{ Material gambut halus } \\
\hline $0-20$ & 263 & 350 & 45.4 & 16.4 & 38.2 \\
$20-40$ & 275 & 368 & 54.3 & 11.4 & 34.4 \\
$40-60$ & 277 & 368 & 57.2 & 10.8 & 32.1 \\
\hline \multicolumn{7}{c}{ Material gambut kasar } \\
\hline $0-20$ & 256 & 340 & 20.7 & 47.6 & 31.7 \\
$40-40$ & 268 & 369 & 54.1 & 11.6 & 34.3 \\
\hline
\end{tabular}

Keterangan:

Tv : suhu ignisi material mudah menguap;

Tc : suhu ingisi char;

$\triangle \mathrm{Wd}$ : beban hilang saat pengeringan;

$\triangle \mathrm{Wv} \quad$ : beban hilang dari material mudah menguap;

Cc : kandungan karbon dari gambut

Tabel 1 ialah hasil penelitian dari Usup, et al. (2004). Berdasarkan tabel tersebut, proses pirolisis dapat terbagi menjadi tiga fase, yaitu:

1. Fase pertama

Fase endotermik dimana kelembaban tanah diserap oleh matriks tanah dan suhu meningkat menjadi $150^{\circ} \mathrm{C}$. Hilangnya berat gambut berkisar antara $20-$ $45 \%$ pada kedalaman $0-20 \mathrm{~cm}, 54 \%$ pada kedalaman $20-60 \mathrm{~cm}$ dan $50-57 \%$ pada kedalaman 40-60 cm.

2. Fase kedua

Setelah gambut mencapai suhu $260^{\circ} \mathrm{C}$, secara bertahap panasnya akan meningkatkan kecepatan pirolisis. Pada fase ini, berat yang hilang dari gambut berkisar antara $10-47 \%$ dan menyebabkan dehidrasi yang menimbulkan pembentukan char carbonaceous yang akan menampakkan cahaya pembakaran.

3. Fase ketiga

Pada fase ini, terjadi pengurangan massa gambut secara cepat.

\subsection{Indeks Citra Satelit}

Pemanfaatan teknologi berupa citra satelit sebagai media untuk mendapatkan informasi penginderaan jauh dalam kurun waktu tertentu menjadi salah satu solusi yang dapat dilakukan ketika bencana kebakaran terjadi. Teknologi penginderaan jauh atau biasa disebut dengan remote sensing merupakan sebuah penyelesaian masalah untuk sebuah penelitian mengenai objek dimana objek yang diteliti tidak harus disentuh secara langsung oleh media. Citra Satelit Sentinel-2 menjadi salah satu jenis citra dengan resolusi spasial tinggi yang dapat digunakan. Satelit Sentinel-2 ini memiliki kemampuan sensor sebanyak 13 band, yakni 4 band memiliki resolusi spasial $10 \mathrm{~m}, 6$ band beresolusi spasial 20m, dan 3 band beresolusi spasial 60m (Kawamuna et al., 2017).

Agar Informasi yang disajikan pada citra dapat tersampaikan maka perlu dilakukan pengolahan dengan cara klasifikasi objek. Dalam studi kebakaran hutan ini dapat dilakukan dengan perhitungan indeks citra. Ada beberapa indeks yang dapat digunakan dalam mendeteksi area kebakaran yakni NBR, NDVI, dNDVI, dan dNBR Kurnaz et al., (2020).

Tabel 2 Formula indeks untuk deteksi area kebakaran (Kurnaz et al., 2020)

\begin{tabular}{|c|c|c|}
\hline Indeks & $\begin{array}{l}\text { Formula untuk } \\
\text { Sentinel-2 }\end{array}$ & Aplikasi dan Kegunaan \\
\hline NBR & $(\mathrm{B} 8-\mathrm{B} 12) /(\mathrm{B} 8+\mathrm{B} 12)$ & $\begin{array}{l}\text { Untuk mendeteksi area } \\
\text { terbakar }\end{array}$ \\
\hline NDVI & $(\mathrm{B} 8-\mathrm{B} 4) /(\mathrm{B} 8+\mathrm{B} 4)$ & $\begin{array}{l}\text { Untuk mendeteksi } \\
\text { vegetasi }\end{array}$ \\
\hline dNDVI & $\begin{array}{l}\text { NDVI } \\
\text { fire fire }\end{array}$ & $\begin{array}{l}\text { Untuk mendeteksi } \\
\text { perubahan vegetasi pasca } \\
\text { kebakaran }\end{array}$ \\
\hline $\mathrm{dNBR}$ & NBR pre fire - NBR post fire & $\begin{array}{l}\text { Untuk mendeteksi bekas } \\
\text { area yang terbakar } \\
\text { dihitung dari pre dan post } \\
\text { image }\end{array}$ \\
\hline
\end{tabular}

Keterangan: NBR: Normalized Burn Ratio ; NDVI: Normalized Difference Vegetation Index ;dNDVI: Differenced NDVI ; dNBR: Differenced NBR.

Dari Tabel 2 dapat diketahui formula yang digunakan sesuai dengan variabel faktor penyebab kebakaran yakni 
adanya perubahan dari area vegetasi. Hal ini terbukti pada penelitian Prayoto et al. (2017) didapatkan bahwa adanya perubahan tipe tutupan lahan utamanya semak dengan persentasi cukup besar yakni 36,8\%. Kemudian, parameter selanjutnya adalah kematangan jenis gambut itu sendiri, tingkat kematangan gambut dapat ditentukan dari rata-rata kadar air yang menggenangi gambut. Ratarata kadar air ini dapat dilihat dari tingkat kelembaban melalui indeks Normalized Difference Water Index (NDWI) (Gao, 1996). Pada tingkat kematangan fibrik dengan kadar air cukup jenuh maka potensi untuk terjadinya kebakaran lebih rendah dibandingkan hemik dan saprik yang memiliki kadar jenuh air yang lebih sedikit. Kadar air yang terkandung pada gambut ini menandakan adanya kelembaban dan terdapat kaitannya dengan kondisi tinggi muka air tanah (Meingast et al., 2014).

Hasil penelitian oleh Febrianti, et al. (2019) menunjukkan bahwa estimasi Tinggi Muka Air Tanah (TMA) dari kombinasi data lapangan dan indeks kekeringan (NDWI) memberikan akurasi yang cukup baik. Hasil prediksi dengan penggunaan indeks, menginformasikan kondisi yang cukup jauh jika dibandingkan dengan keadaan fluktuatifnya tinggi muka air tanah dan cara ini termasuk cukup cepat untuk dapat dibuatkan pemodelan estimasi TMA.

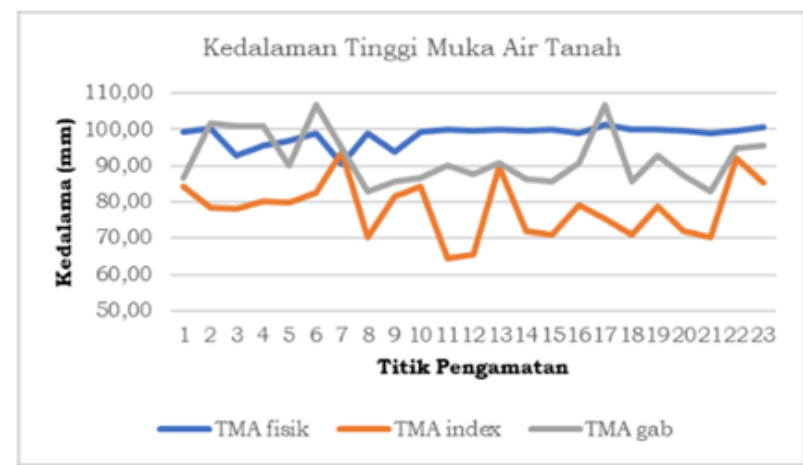

Gambar 2 Kondisi TMA setiap model pada saat hotspot

(N.Febrianti, et.al., 2019)

Meskipun demikian, model estimasi TMA ini belum tentu dapat diterapkan secara langsung pada lokasi penelitian lainnya. Kedalaman muka air tanah lahan gambut hendaknya tetap dipertahankan kurang dari titik kritis, jika tidak, maka potensi kebakaran lahan gambut akan meningkat.

Kondisi iklim ataupun curah hujan yang terjadi akan berkaitan erat pula dengan tinggi muka air yang terkandung di dalamnya. Peristiwa kebakaran akan sangat rendah apabila musim hujan telah stabil, dimana hampir setiap hari turun hujan. Pada kondisi ini hutan dan lahan gambut akan tergenang oleh air sehingga bahan bakar mempunyai kadar air tinggi dan sulit terbakar (Adinugroho, 2004). Hal ini selaras dengan penelitian As'ad Humam, et al. (2020), peta sebaran curah hujan dapat digunakan untuk menganalisis potensi kerawanan kebakaran hutan dan lahan. Semakin tinggi tingkat curah hujan suatu wilayah maka semakin rendah tingkat kerawanan kebakaran pada wilayah tersebut. Hasil proses Weighted Overlay, menunjukkan parameter yang berperan besar berupa suhu permukaan dan curah hujan. Provinsi Jambi memiliki musim kemarau yang lebih lama dibandingkan musim hujan, hal ini berpengaruh terhadap intensitas curah hujan pada kawasan Jambi sebagai parameter terbesar penunjang potensi kerawanan kebakaran hutan. Suhu permukaan menjadi pendukung kuat terhadap potensi kebakaran lahan dan hutan, akibat tingginya suhu yang diberikan ke lahan gambut tanpa disertai curah hujan yang berintensitas tinggi.

\subsection{Pemilihan dan Pengembangan Model Algoritma Machine Learning Metode Random Forest}

Peta kerawanan kebakaran hutan menunjukkan kemungkinan suatu area akan terjadi kebakaran di masa depan, berbasis hanya melalui sifat intrinsik lokal dari daerah tersebut. Studi terkini di bidang ini sering mengandalkan model statistika, yang ditingkatkan oleh pengetahuan ahli untuk pengambilan dan pemrosesan data. Pada beberapa tahun ke belakang, algoritma machine learning terbukti sukses pada bidang ini, berkat kemampuannya untuk belajar dari data lewat pemodelan dari hubungan tersembunyi yang ada di dalamnya. Pada studi Tonini, et al. (2020) ia memperkenalkan pendekatan yang berbasis metode random forest (RF) untuk mengembangkan peta kerawanan kebakaran hutan untuk daerah Liguria di Italia. Daerah ini sangat rawan oleh kebakaran hutan karena vegetasinya yang padat dan heterogen, dengan lebih dari 70\% permukaannya ditutupi oleh hutan, serta kondisi iklim yang merugikan. Kerawanan dinilai dengan memperhitungkan set data dari lingkar api yang terpetakan yang mencakup periode selama 21-tahun (1997-2017) dan berbagai faktor geolingkungan yang mempengaruhinya (contoh., land cover, tipe vegetasi, jaringan jalan, ketinggian, dan lereng).

Potensi RF dalam menganalisis citra satelit multispektral dikaji pada penelitian Lowe, et al. (2015) di Mississippi menggunakan beragam metode klasifikasi seperti maximum likelihood, neural network, support vector machine, dan $\mathrm{RF}$ lalu membandingkan hasilnya sebagaimana yang tercantum pada Tabel 3 .

Tabel 3 Tingkat Akurasi setiap Machine Learning

\begin{tabular}{ccccc}
\hline & $\begin{array}{c}\text { Random } \\
\text { Forest }\end{array}$ & $\begin{array}{c}\text { Neural } \\
\text { Network }\end{array}$ & $\begin{array}{c}\text { Support } \\
\text { Vector } \\
\text { Machine }\end{array}$ & $\begin{array}{c}\text { Maximum } \\
\text { Likelihood }\end{array}$ \\
\hline $\begin{array}{c}\text { Akurasi } \\
\text { Keseluruhan }\end{array}$ & $\mathbf{9 6 . 2 5 \%}$ & $76.87 \%$ & $86.88 \%$ & $83.13 \%$ \\
\hline Kappa & $\mathbf{0 . 9 5}$ & 0.6917 & 0.825 & 0.775 \\
\hline
\end{tabular}

(Leuenberger, et.al., 2013)

Berdasarkan Tabel 3, metode RF unggul dibanding metode lainnya dilihat dari akurasi keseluruhannya. Metode RF bekerja dengan baik karena training data yang besar dan homogen. Dengan pilihan variable pseudorandom untuk setiap node yang terpisah, metode RF 
mengembangkan banyak jenis decision trees yang tidak menghasilkan nilai balik yang sama, sehingga dengan sistem komitenya, menghasilkan nilai balik yang memiliki akurasi lebih baik dari algoritma machine learning lainnya (Leuenberger, et al., 2013).

\section{Kesimpulan}

Kebakaran di lahan gambut sulit diprediksi akibat ekosistem gambut yang kompleks. Banyaknya variabel yang harus diperhitungkan dalam penelitian gambut, membuat harus ditemukannya hubungan antar variabel tersebut. Dengan menggunakan kemampuan bantuan algoritma machine learning yang mampu belajar dari data lewat pemodelan dan hubungan tersembunyi di dalamnya, hubungan antar variabel tersebut dapat dicari. Algoritma machine learning yang digunakan ialah metode $\mathrm{RF}$ dikarenakan besarnya training data yang tersedia dan keakuratan metode RF dalam mengolah banyak data yang tidak saling berhubungan dengan akurasi mencapai 96\%. Adapun variabel-variabel faktor penyebab kebakaran yang berhasil diidentifikasi melalui perhitungan indeks citra sentinel-2 ialah: tingkat vegetasi di lokasi kebakaran, ground water level, suhu, kematangan jenis gambut, curah hujan, dan durasi kebakaran.

\section{Pernyataan Konflik Kepentingan}

Penulis tidak ada konflik kepentingan dalam artikel ini.

\section{Referensi}

Adinugroho, W.C, I N.N. Suryadiputra, B.H. Saharjo, L. Siboro. (2004). Panduan Pengendalian Kebakaran Hutan dan Gambut. Edisi ke-1. Wetlands International. Bogor.

Babrauskas, Vytenis. (2003). Ignition Handbook. 1, Fire Science Publishers

Ratnaningsih A. T., dan Prasetyaningsih S. R. (2017). IOP Conf. Ser.: Earth Environ. Sci.97 012029

Febrianti, N, K. Murtilaksono, B. Barus. (2019). Pengaruh Tinggi Muka Air Gambut Sebagai Indikator Peringatan Dini Bahaya Kebakaran Di Sungai Jangkang - Sungai Liong. Jurnal Penginderaan Jauh. 16 (1) :9-19.

Gao, B-C. (1996). Ndwi-A Normalized Difference Water Index for Remote Sensing of Vegetation Liquid Water From Space. Remote Sensing of Environment, 58: 257266.

Hayasaka, Hiroshi \& Usup, Aswin \& Naito, Daisuke. (2020). New Approach Evaluating Peatland Fires in Indonesian Factors. Remote Sensing.

Ishii, Yoshiyuki \& Koizumi, Ken \& Fukami, Hiroshi \& Yamamoto, Koichi \& Takahashi, Hidenori \& Limin,
Suwido \& Kusin, Kitso \& Usup, Aswin \& Susilo, Gatot. (2016). Groundwater in Peatland.

Kasihairani, Dara \& Virgianto, Rista \& Risnayah, Siti. (2014). Dampak El Niño Southern Oscillation Dan Indian Ocean Dipole Mode Terhadap Variabilitas Curah Hujan Musiman Di Indonesia.

Kawamuna, A., Suprayogi, A., Wijaya, AP. (2017). Analisis Kesehatan Hutan Mangrove berdasarkan Metode Klasifikasi NDVI pada Citra Satelit Sentinel-2 . Jurnal Geodesi Undip . 6(1): 277-284.

Kurnaz, B., Bayik, C. B., Abdikan, S. (2020). Forest Fire Area Detection by Using Landsat-8 and Sentinel-2 Satellite Images: A Case Study in Mugla, Turkey .

Leuenberger, Michael \& Kanevski, Mikhail \& Vega Orozco, Carmen. (2013). Forest Fires in a Random Forest.

Lowe, Barrett \& Kulkarni, Arun. (2015). Multispectral Image Analysis Using Random Forest. International Journal on Soft Computing. 6. 1-14. 10.5121/ijsc.2015.6101.

Masganti. (2014). Karakteristik dan Potensi Pemanfaatan Lahan Gambut Terdegradasi di Provinsi Riau.

Meingast, K. M., Falkowski, M. J., Kane, E. S., Potvin, L. R., Benscoter, B.W., Smith, A.M.S., Bourgeau-Chavez, L. L., Miller, M.E. (2014). Spectral Detection of Near-surface Moisture Content and Water-table Position in Northern Peatland Ecosystem. Remote Sensing of Environment. 152:536 -546.

Prayoto, M.I. Ishihara, R. Firdaus, And N. Nakagoshi. (2017). Peatland Fires In Riau, Indonesia, In Relation To Land Cover Type, Land Management, Landholder, And Spatial Management. Journal of Environmental Protection . 8:1312-1332

Tonini, M.; D'Andrea, M.; Biondi, G.; Degli Esposti, S.; Trucchia, A.; Fiorucci, P. A. (2020). Machine LearningBased Approach for Wildfire Susceptibility Mapping. The Case Study of the Liguria Region in Italy. Geosciences. 10: 105.

Usup, Aswin \& Hashimoto, Yoshihiro \& Takahashi, Hidenori \& Hayasaka, Hiroshi. (2004). Combustion and thermal characteristic of peat fire in tropical peatland in Central Kalimantan, Indonesia. Tropics. 14. 1-19. 10.3759/tropics.14.1.

Yiu, T. (2019). Understanding Random Forest: How The Algorithm Works and Why It Is So Effective, websites, https://towardsdatascience.com/ understandingrandom-forest, Accessed on 12 November 202 